\title{
OBSERVING NORMS AND ANOMY AMONG THE YOUTH: A CASE OF MADAGASCAR
}

\author{
Iavo Ramananarivo \\ Email: mananaramananarivo@gmail.com \\ UNIVERSITE D'ANTANANARIVO Ecole Doctorale Sciences Humaines et Sociales (ED- \\ SHS) EAD-Rouages des Sociétés et Développement (EAD-ROSODEV) DOMAINE DES \\ SCIENCES DE LA SOCIETE (DSS) MENTION SOCIOLOGIE (FACULTE DE DROIT, \\ D'ECONOMIE, DE GESTION ET DE SOCIOLOGIE)
}

Submitted

December 23, 2019
Revised

December 30, 2019

https://doi.org/10.17509/jpis.v28i2.22140
Accepted

December 30, 2019

\section{ABSTRACT}

This paper systematically addresses different concepts of anomy and norms among young men from selected groups in society. Government authorities in Madagascar who are responsible for public education are concerned about the social changes we are experiencing collectively. They have a more elaborate and better vision to guide young people in a professional and social world. In this perspective, they recognize that globalization, for example, is gradually creating a new phenomenon, in this case: technology. Many people believe that citizenship education enables adolescents to cope with these changes, since from this perspective, the child from birth is seen as part of a community, to whom he or she will eventually contribute. Citizenship is a mechanism that consolidates and convinces the future citizen of the importance of his social and political involvement and the valorization of his identity roots.

Keywords: Values, Responsibility, Integrity

\begin{abstract}
ABSTRAK
Artikel ini secara sistematis membahas berbagai konsep anomi dan norma di antara para remaja putra dari kelompok-kelompok terpilih dalam masyarakat. Otoritas pemerintah di Madagaskar yang bertanggung jawab atas pendidikan publik prihatin dengan perubahan sosial yang kita alami secara kolektif. Mereka memiliki visi yang lebih rumit dan lebih baik untuk membimbing kaum muda di dunia profesional dan sosial. Dalam perspektif ini, mereka mengakui bahwa globalisasi, misalnya, secara bertahap menciptakan fenomena baru, dalam hal ini: teknologi. Banyak orang percaya bahwa pendidikan kewarganegaraan memungkinkan remaja untuk mengatasi perubahanperubahan ini, karena dari perspektif ini, anak sejak lahir dipandang sebagai bagian dari komunitas, kepada siapa ia pada akhirnya akan berkontribusi. Kewarganegaraan adalah suatu mekanisme yang mengkonsolidasikan dan meyakinkan warga negara masa depan tentang pentingnya keterlibatan sosial dan politiknya dan pengukuhan akar identitasnya.

Kata kunci: Nilai, Tanggung Jawab, Integritas
\end{abstract}

\section{INTRODUCTION}

Education is a human right, plays an imporant role, and enables access to the other rights [1]. In addition, it is also a pillar of human development [2]. This position and this role are reinforced today by the new trends that affect the global environment: globalization, the emergence of the New Information and Communication Technology (NICT) [3]. Science and knowledge have thus become essential factors in the 
economic development of a country [4]. The UNESCO has been promoting global citizenship education since the launch in 2012. The UN Secretary-General of the Global Initiative has put, first and foremost, a special emphasis on education that made the promotion of global citizenship one of its three priorities in education [5].

The theme of citizenship is often associated today with "citizenship education" or "civic education" at school. The potential of citizenship education in bringing global issues to the curriculum and understanding and responding to global challenges is explored [6]. Citizenship education enables students to acquire a delicate balance of cultural, national, and global identifications and to understand the ways in which knowledge is constructed; to become knowledge producers; and to participate in civic action to create a more humane nation and world [7]. Citizenship education should also help students to develop an identity and attachment to the global community and a human connection to people around the world [8]. The promotion of global citizenship education is particularly relevant to discussions about global education or education for peace, democracy and human rights [9]. Citizenship education presented by the public authorities and the media as remedies for the rise of incivility and violence in neighborhoods or schools. These are the source of a growing sense of insecurity and "social disintegration" and a major issue in today's society [10]. Hence the temptation to directly connect the two, which are "crisis of civility or citizenship" and the new technology of information and communication. What particularly interests us is the general weakening of the regulatory capacities of the socialization authorities [11].

Regardless the analysis of the manifestations and the causes of a "crisis of citizenship", it is simply a matter of recalling all realities, and in particular the various dimensions of the citizen culture [12]. This regulatory principle appears more than ever necessary in the modern world, including the revitalization of young man in their fundamental function of socialization and in their future life. We often say that Madagascar is rich, but its population is poor or impoverished. To say the opposite would be absurd. In 2013. Madagascar ranked 157th out of 187 countries in the Human Development Index (HDI) of the United Nations Development Program (UNDP) [13]. Two years later, in 2015, the situation worsened as the country regressed to 169th place. As all the criteria show, Madagascar is one of the poorest countries in the world [14]. In Madagascar, the link between poverty and drift in terms of citizenship among young man today is generally at the macroeconomic level in terms of change. However, what about the development of technology and the education of young man? A third variance is played out in terms of development among them. We can also note that currently, the population is not interested in their life of cohesion and culture, which recently, is caused by the lack of education in citizenship and the multiplication of social networks or the manipulation of the internet directly. Giving a value to learning is a good start for a new vision of citizenship.

\section{METHOD}

Self-determination approach: A young man will be more motivated if he 
considers things as the source and main cause of his actions and if he feels competent. The individual is engaged in more autonomous behavior in order to obtain something [15]. Then he is engaged in an activity for himself and the reinforcement comes after during the activity. The ability to refer to the past and to anticipate the future gives aspirations for the future. A young man is able to observe others and draw conclusions from himself which makes him aware and responsible. Observing others is not a passive, but an active act and can help to motivate an individual to engage in activities that he or she apprehends. The "structuralfunctionalism" approach will enable us to study the functioning of this elementary structure and its evolution. Culturalism, like its precursors, is part of psychoanalytic elements that shape the structure of the personality. If we merge "structure" and "culture", we come to the term of cultural identity or identity culturality in terms of objectivity [16]. Phenomenological approach: it is a question of grasping the lived experience of a young man and the entourages which will be the object of our observation. Set up a citizenship education through an active and responsible participation of students (class and school councils, organization of freedoms and responsibilities, participatory approach and projects) [17].

\section{Qualitative method}

Technique of direct observation: which will allow us to verify in the field which mean an objective vision of realities from an observation grid. The researcher describes, takes notes the behaviors of participants as they occur, such as the behaviors of youth, teachers, groups in the classroom or in our group discussion. This technique makes it possible to identify the manifestation of the behaviors where they will be able to confront the observations according to the statements of the participants. Group discussions in classes and facebook.

Social surveys were conducted as well as the development of a list of questionnaires to be asked of the target groups. These surveys were conducted during activity monitoring and semiopen questionnaires distribution to obtain data; field study to meet the target youth; and interview with the trainers who are none other than the staff of the OEMC (Office of Mass Education and (ivic). We also had to have a group discussion to better integrate the groups and obtain free and tangible information on qualitative and quantitative analysis.

\section{FINDINGS AND DISCUSSION}

The negative impact of the failure of primary socialization on the behavior of young man.

Young man today is more and more unstable and worrisome of life, of know-how to be, and of know-how. They have much more ambition but the realization on the know-how and the know-how to be seems lacking for all the generations of the future. For decades, these individuals have lived only the present without thinking of the future life. However, it turns out that society has changed and marked them no longer exist for young man today. Adults have a negative view of the lives of young man today, such as disrespectful. As a result, parents do not understand the behavior of young man. In turn, they feel frustrated and assaulted.

The adults, overwhelmed, wonder if their children are "normal". 
For young man, the individual is ahead of the group, the identity is individual. They forge their own identity and stand out. They must be noticed, permanently, so that their identity lives. Following this desire, they feel dissatisfied, his world is threatened. Hence for the them, security is primordial.

The young man expresses themselves with a very different expression: a very slang language, a different gesture for each word while clapping their hands, etc. Continuing with the group discussion, they can not concentrate without their phone, they start to share the discussions we made. We have touched on the subject directly with the use of the internet. How they perceive Malagasy cultural value and technological news. We understand that they speak with certainty and dynamism during the survey when it concerns to social networks and the behavior of youth today. A cultural identity has been formed among them based on globalization, if we draw from from the work of Pierre MERCKLE in "the sociology of social networks", 2011. Facebook has entered the world of communication, which is used only in an American university. We can also say that Malagasy inculcate the value of Americans using Facebook. To use the network well, you need an apprenticeship. About that, Ralph LINTON says in his book The Cultural Foundation of the Personality, 1945. First, culture is the foundation of the social structures themselves; any institution is ultimately translated into a system of behaviors imposed on individuals, behaviors that they must learn.
The technological revolution and the generational changes are factors favoring this thought of ethics

Parents can not get rid of this life. Young man manages to control their parents, as if the responsibility of everyone in a family is confused. National education also promotes these technological advances by evaluating students on presentations, distributing tablets for secondary and high school students in certain region of Madagascar35. That is why we can not dissociate the world from technology with young man. We can say that this is their major occupation. Technology is gaining more and more place in society.

Young man has less and less loneliness's life, focused on network life and sharing with the electronic machine. They connect daily, and in the end forget the reality. It is in the social networks that they make use when they have problems. In the previous table, they are waiting for solutions on Facebook. They consider the opinions of others, especially those around them, even the opinion of their parents. They only do what their thinks good like in the internet, just typing solutions in the internet, the answer appears as if by magic, while the proposed solutions are unsatisfactory.

The survey conducted in schools and Facebook users aged 11 to 16, tends to show that most of the dangers associated with Internet for the young man are generally overestimated. This study also shows that parents often have a wrong assessment of what their children consider a traumatic or unpleasant experience. All participants say they were bored or bothered by something on the internet. However, most of them do not report any particular problem or concern about the 
internet. They are sensitive to threats or to fear.

\section{CONCLUSION}

To convey moral values, we must not detach ourselves from the traditional system. This is why parents or educators must be positive at all times. They will be able to accompany them and convey to them the respect and the art of empowerment with the new technology and communication. However, during the phases of a youth's life, the experiencing with new situations and new peoples will engender a construction of their identity. Yet, how can we achieve this education or modern education? Since the use of Information and Communication Technologies has become unavoidable in today's society, young man show great ease in the use of these tools, but it is necessary to help them to have a wise use of these tools.

The question of citizenship of young people is inseparable from their social existence; it is based on the "right of citizenship" for all. This question asks what would be a "just society", which would think of the same movement of development of the public space, recognition of the plurality within it and collective redefinition of the "common good". When using the internet, it is useful to remind students of their commitment when signing the charter but also the risks for them. We must ensure the respect of good manners and good practices on the Internet. It defines rules of good behavior to follow in the email, the file transfer, the discussion forums, etc. It is the foundation of youth's awareness of the Internet.

\section{BIBLIOGRAPHY}

[1] M. Sinclair, "Education in emergencies Past employment View project," 2001.

[2] E. A. Hanushek, "Education and Economic Growth," 2010.

[3] S. Livingstone, "Media literacy and the challenge of new information and communication technologies," Commun. Rev., vol. 7, no. 1, pp. 3-14, 2004.

[4] D. B. Audretsch, "Entrepreneurship capital and economic growth," Oxford Rev. Econ. Policy, vol. 23, no. 1, pp. 6378, Mar. 2007.

[5] M. Schweisfurth, "Education for global citizenship: Teacher agency and curricular structure in Ontario schools," Educational Review, vol. 58, no. 1. pp. 41-50, Feb-2006.

[6] T. Ibrahim, "Global citizenship education: Mainstreaming the curriculum?," Cambridge Journal of Education, vol. 35, no. 2. pp. 177-194, Jun-2005.

[7] J. A. Banks, "Citizenship education and diversity: Implications for teacher education," J. Teach. Educ., vol. 52, no. 1, pp. 5-16, 2001.

[8] J. A. Banks, "Diversity, Group Identity, and Citizenship Education in a Global Age," 2008.

[9] A. Osler and K. Vincent, "Citizenship and the challenge of global education," 2002.

[10] B. McSweeney, "Maximizing shareholder-value: A panacea for economic growth or a recipe for economic and social disintegration?," Crit. Perspect. 
Int. Bus., vol. 4, no. 1, pp. 55-74, 2008.

[11] J. G. Blumler, "Origins of the crisis of communication for citizenship," Polit. Commun., vol. 14, no. 4, pp. 395-404, Oct. 1997.

[12] P. Geschiere and S. Jackson, "Autochthony and the Crisis of Citizenship: Democratization, Decentralization, and the Politics of Belonging," Afr. Stud. Rev., vol. 49, no. 2, pp. 1-8, 2006.

[13] A. K. Shiva Kumar, "UNDP's Human Development Index: A Computation for Indian States," Economic and Political Weekly, vol. 26. Economic and Political Weekly, pp. 2343-2345.
[14] B. Minten, L. R.-... development and poverty, and undefined 2007, "12 Global Supply Chains, Poverty and the Environment: Evidence from Madagascar," books.google.com.

[15] R. Mc Corquodale, "Selfdetermination: A human rights approach," Int. Comp. Law Q., vol. 43, no. 4, pp. 857-885, 1994.

[16] R. Frie, "What is cultural psychoanalysis? Psychoanalytic anthropology and the interpersonal tradition," Contemp. Psychoanal., vol. 50, no. 3, pp. 371-394, 2014.

[17] W. Carr, "Education for Citizenship," Br. J. Educ. Stud., vol. 39, no. 4, pp. 373-385, 1991. 